\title{
The Development of Teaching Materials Explanatory Text Based on Interactive Multimedia of Students Class XI SMA Negeri 1 Sunggal
}

\author{
Victorya Sianipar \\ Postgraduate Program \\ State University of Medan \\ Medan, Indonesia \\ victoryasianipar85@yahoo.co.id
}

\author{
Biner Ambarita \\ Postgraduate Program \\ State University of Medan \\ Medan, Indonesia
}

\author{
Abdurrahman Adisaputera \\ Department of Indonesian Language \\ State University of Medan \\ Medan Indonesia
}

\begin{abstract}
This study aims to produce teaching materials explanatory text based on multimedia interactive of students class XI SMA Negeri 1 Sunggal. The product of teaching materials produced is $C D$ interactive. The method used in Research and Development (R\&D) method with ADDIE development model. The trials carried out were expert trials or product validation by media and material experts, field practitioner trials conducted by Indonesian teachers, limited trials conducted on small groups as product users, field trials involving subjects 32 users of class XI MIA 1. The results of this study indicate that (1) the percentage of feasibility of teaching materials as much as $78,1 \%$ of appearance and $83,9 \%$ programming by media experts, $82,8 \%$ content and $83,9 \%$ by material experts in the category of very feasible, (2) $55,55 \%$ of teachers and students recognize interactive multimedia and $44,44 \%$ of teachers and students do not recognize interactive multimedia; $38,88 \%$ of teachers and students had used interactive multimedia in learning, $61,11 \%$ of teachers and students had never used interactive multimedia in learning; $97,22 \%$ of teachers and students stated that interactive multimedia is needed in learning activities in the classroom and $0,027 \%$ of teachers stated that they did not need interactive multimedia, (3) the pretest of students when utilizing textbooks containing images in the book as their media reached 2350 with an average of $73,43 \%$ with sufficient criteria, the posttest results after using PowerPoint 2010 interactive multimedia based teaching materials obtained a value of 2725 with an average of $85,15 \%$.
\end{abstract}

Keywords-development; teaching materials; explanatory text; based on multimedia interactive

\section{INTRODUCTION}

The development of science and technology in the era of globalization has an impact on the progress of the quality of education, one of which is in improving learning. Learning is an activity that involves a person in an effort to obtain knowledge, skills, and positive values by utilizing various sources for learning. Learning basically addresses the question of what, who, why, how, and how capable of following the lesson. The question of how capable is related to the teachers ability to plan and implement the learning process in the classroom. The ability of teachers in planning learning can be seen from the teaching materials that have been prepared in advance.

The results of observations say that very often teachers who teach only provide subject matter without preparing in advance the material to be taught. The teacher only carries one book that is the student handbook given by the school without being modified to be taught, so students have not been able to understand and write explanatory texts well in terms of EYD, structure, and linguistic rules in accordance with the writing of explanatory texts. The use of media, especially multimedia, is really needed to have a positive impact on KKM achievement and increase students' understanding of text learning in this case explanatory texts

\section{METHOD}

The method used in this research and development ( $\mathrm{R} \&$ D) method with development model of ADDIE. The ADDIE model consists of five steps:

\section{A. Analysis}

The first stage is analysis. The analysis was carried out to find out the purpose of developing this multimedia and for whom this multimedia was intended. The analysis phase of this study includes the analysis of the characteristics of the XI grade students of SMA Negeri 1 Sunggal by observation; and media analysis carried out by discussing with supervisors, subject teachers, media experts and various references.

\section{B. Design}

The second stage is design. This design phase includes activities:

1) Setting Learning Objectives :Determination of learning objectives made in this media is that students can understand explanatory text learning and matters relating to explanatory text such as structure, language rules, and how to produce after learning interactive explanatory text based teaching materials. 
2) Presentation of Material: Materials collected based on needs analysis that have been carried out include: to fill in the material, referring to Indonesian textbooks by Engkos Kosasih, Indonesian textbooks by Handiyani for class XI SMA/MA, and other sources related to explanatory text material ; to create multimedia based teaching materials, using Microsoft PowerPoint 2010 applications and supporting applications using Adobe Photoshop.

3) Writing Media Media and Materials

4) Storyboarding

5) Formulation of Evaluation Tools

\section{Development}

The third stage is development. This stage includes activities:

1) Making Learning Media : Making learning media starts from typing the material, practice questions, evaluating, and proceed by inserting images, making animations, and navigation. Some media creation displays, namely the opening page there is a "Enter" button which will take the user to the next page; the menu contains information about the navigation buttons on this learning media; main menu material is a page that contains submenus of materials in this learning media; the first submenu is the explanation of explanatory text; The second submenu of explanatory text structure; The third submenu features explanatory text language; the fourth submenu for producing explanatory texts; Evaluation menu is a page of multiple choice practice questions with five answer choices to be done by the user; glossary menu is a page that contains difficult vocabulary related to the material and vocabulary in the learning media as a whole; The profile menu contains a brief profile of the instructors of learning media; Bibliography menu contains names of references or references.

2) Media Revision : Media revision is done to determine the feasibility of the media being developed.

\section{Implementation}

Multimedia that has been validated by experts is then tested in the field. This trial was carried out in 35 students of SMA Sunggal 1 class XI MIA 1. A trial was conducted to determine the assessment of students as users. The trial was conducted in a computer laboratory room. Each student tries learning media on their respective computers. The end of the meeting was given a closed student assessment questionnaire containing several questions. Obtaining data in this trial regarding student assessment. The trial results are used to revise teaching materials. Data from the trial results are then analyzed to find out whether the learning tools that the researchers have developed are included as appropriate criteria or not.

\section{E. Evaluation}

This stage is obtained by analyzing the results of the evaluation sheet data obtained from media experts, material experts, teachers and students. This analysis is based on the results of a questionnaire that has been filled out by media experts, material experts, teachers and students.

\section{RESULTS}

The results of the validation of the media experts on the feasibility of interactive multimedia-based teaching materials show that the interactive learning media developed viewed from the display aspect had a percentage of $78.1 \%$ categorized as having very good criteria, the operational aspect of developing interactive learning media had a percentage of $83.9 \%$ categorized as getting very good criteria to use for students.

The results of the validation of the material experts on the feasibility of interactive multimedia-based teaching materials show that the interactive learning media developed viewed from the aspect of content / material has a percentage of $82.8 \%$ categorized as having very good criteria, the aspect of developing interactive learning media programming has a percentage of $83.9 \%$ categorized as getting very good criteria. The average percentage of results from both aspects is $83.35 \%$ with the criteria very feasible to use for students.

The results of the data obtained by teachers and students obtained 1) $55.55 \%$ of teachers and students were familiar with interactive multimedia and $44.44 \%$ of teachers and students were not familiar with interactive multimedia; 2) as many as $38.88 \%$ of the teachers stated that they had used interactive multimedia and students said the teacher had used interactive multimedia in learning, but most students stated that the teacher had never used interactive multimedia in learning and the teacher himself stated that they had never used interactive multimedia as much as $61.11 \%$; 3) $97.22 \%$ of teachers and students stated that interactive multimedia was needed in learning activities in the classroom and $0.027 \%$ of teachers said that they did not need interactive multimedia.

The effectiveness test found that the learning outcomes of students increased after using instructional materials based on interactive multimedia PowerPoint 2010. Students' pretest results when utilizing textbooks containing images in the book as a medium before using interactive multimedia based learning materials PowerPoint 2010 reached 2230 with an average value of $73.43 \%$ with sufficient criteria. While the results of the posttest after using interactive multimedia-based teaching material PowerPoint 2010 obtained a value of 2725 with an average of $85.15 \%$, so the teaching material is categorized as effective and suitable for students to use.

\section{CONCLUSION}

The development of teaching materials explanatory text based on interactive multimedia that generate a media has gona through several steps of assesment (validation) and responses. Based on the results of the assesment (validation) by materials experts and design experts, as well the responses of teacher and the responses of students as the subjects trial, it can be concluded that this study has produced a product of teaching materials in the form of explanatory text based on interactive multimedia Powerpoint 2010 that is feasible and good for a implemented in the class SMA Negeri 1 Sunggal as a 
companion teaching materials and supporting the continuity of learning activities and to improve the quality of learning in school.

\section{REFERENCES}

[1] Depdiknas. 2008. Guidelines for Developing Teaching Materials. Directorate General of Primary and Secondary Education Management, Directorate of High School Education.
[2] Harijanto, Mohammad. 2007. Development of Teaching Materials for Improving Learning Quality in Elementary School Learning Education Programs. Didactics Journal Vol. 2 No. 1 March

[3] Handiyani, et al. 2014. Indonesian Language 2 for Class XI High School Compulsory Group. Bandung: Grafindo Media Pratama.

[4] Kosasih, Engkos. 2013. Smart Indonesian Language for SMA / MA Class XI Mandatory Groups. Jakarta: Erlangga.

[5] Sugiyono. 2014. Quantitative, Qualitative, and R\&D Research Methods. Bandung: Alfabeta.

[6] Susilana, Rudi. 2007. Learning Media. Bandung: CV Wacana Prima 